\title{
Practical insights on enzyme stabilization
}

\author{
Carla Silva ${ }^{\mathrm{a} *}$, Madalena Martins ${ }^{\mathrm{a} *}$, Su Jing ${ }^{\mathrm{b}}$, Jiajia Fuc and Artur Cavaco-Paulo ${ }^{\mathrm{a}, \mathrm{b}}$ \\ ${ }^{a}$ Centre of Biological Engineering (CEB), University of Minho, Braga, Portugal; ${ }^{b}$ International Joint Research Laboratory for Textile and \\ Fiber Bioprocesses, Jiangnan University, Wuxi, China; ${ }^{C}$ Key Laboratory of Science and Technology of Eco-Textiles, Ministry of Education, \\ Jiangnan University, Wuxi, Jiangsu, China
}

\section{ABSTRACT}

Enzymes are efficient catalysts designed by nature to work in physiological environments of living systems. The best operational conditions to access and convert substrates at the industrial level are different from nature and normally extreme. Strategies to isolate enzymes from extremophiles can redefine new operational conditions, however not always solving all industrial requirements. The stability of enzymes is therefore a key issue on the implementation of the catalysts in industrial processes which require the use of extreme environments that can undergo enzyme instability. Strategies for enzyme stabilization have been exhaustively reviewed, however they lack a practical approach. This review intends to compile and describe the most used approaches for enzyme stabilization highlighting case studies in a practical point of view.

\section{ARTICLE HISTORY}

Received 9 November 2016

Revised 4 January 2017

Accepted 17 May 2017

\section{KEYWORDS}

Stabilization; enzymes; formulation; molecular interactions; industrial catalysis

\section{Industrial demands of enzymes}

Major applications of enzymes are in industries of detergents, food processing, animal nutrition, juice and flavorings, cosmetics, medication, pharmaceuticals, leather, silk, chemical, and for research and development $[1,2]$. The industrial applications are only feasible if catalysts are stabilized against temperature, extreme $\mathrm{pH}$, and in the presence of alkalis, acids, salts, and surfactants $[3,4]$. Major applications of enzymes are at high temperature (e.g. washing at $60-70^{\circ} \mathrm{C}$, starch gelatinization at $100^{\circ} \mathrm{C}$, textile desizing at $80-90^{\circ} \mathrm{C}$ ), or may vary depending on the substrate and product solubility and stability. They can occur under high salt concentration (food industry) and alkaline conditions and/or in the presence of surfactants (detergents). Reactions can be realized at gas-liquid interface (for reactions consuming (e.g. $\mathrm{O}_{2}$ ) or producing (e.g. $\mathrm{CO}_{2}$ ) gas), liquid-liquid interface for aqueous-organic two-liquid phase reactions where organic phase is used as a carrier for the substrate and/or product and in the presence of organic solvents $[3,5]$. Hence, the need to stabilize enzymes against thermodeactivation, deactivation in the presence of surfactants and alkaline $\mathrm{pH}$ is imperative [6]. Enzyme stability can be enhanced following different routes which include strategies for stabilization in aqueous and non-aqueous environments.

\section{Enzyme properties and the need of stabilization strategies}

Enzymes are protein molecules consisting of folded polypeptide chains of amino acids that are essential to perform an array of biological functions. The order of these amino acids in a protein determines its tertiary structure through molecular geometry and intramolecular chemical interactions $[7,8]$. Depending on the amino acid composition, these proteins can incorporate both acidic and basic functional groups, which play an important role in their structure. Therefore, their expression can be related to resistance of unfolding forces because of protein's conformation results in a less soluble state due to the occurrence of structural changes, aggregation, and/or precipitation [9]. Enzyme's solubility can change as their structure undergoes modifications resulting from the exposure of different residues to the surrounding environment. A few of the remarkable features of enzymes are their functional diversity and versatility derived from each constituent amino acid having a different side chain with a specific chemistry and polarity, and from flexible and numerous ways in which polypeptide chains can fold.

Enzymes undergo a variety of denaturation reactions during production, storage, and their application in industry. Denaturation is the unfolding of the tertiary

CONTACT Artur Cavaco-Paulo artur@deb.uminho.pt 0 Centre of Biological Engineering, University of Minho, 4710-057 Braga, Portugal

*These authors contributed equally to this work.

(C) 2017 Informa UK Limited, trading as Taylor \& Francis Group 
(a)

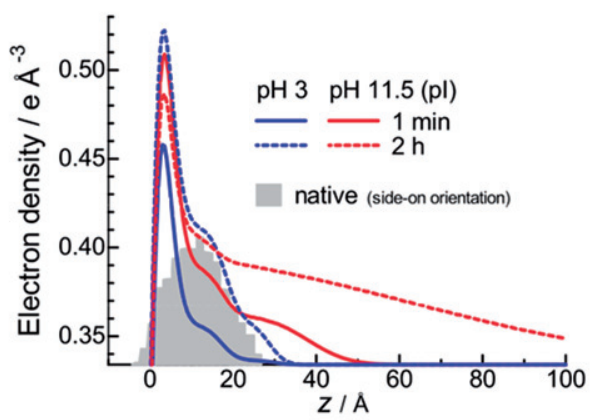

(b)

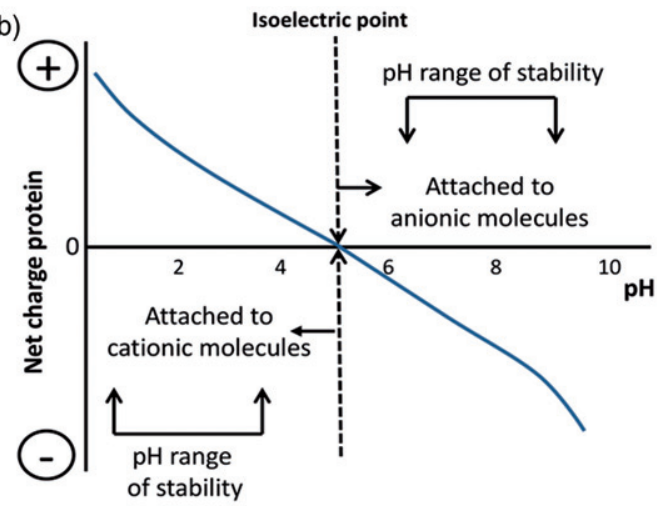

\begin{tabular}{l|l|l}
\hline Type of denaturant & Protein target & Product of denaturation \\
\hline Heat & Hydrogen bonds & Aggregates \\
\hline Cold & Hydrophobic bonds; solvated groups & $\begin{array}{l}\text { Aggregates } \\
\text { Inactive monomers }\end{array}$ \\
\hline Mechanical forces & Solvated groups & $\begin{array}{l}\text { Highly desordered structure; inactive } \\
\text { monomers }\end{array}$ \\
\hline Radiation & Functional groups: cysteine, peptide bonds & Highly desordered structure \\
\hline Proteases & Peptide bonds & Oligopeptides; aminoacids \\
\hline
\end{tabular}

Figure 1. Illustration of (a) electron density profiles perpendicular to the air/water interface for lysozyme injected into buffer solutions with pH 3 and pH 11.5 (pl) (adapted from Yano et al. [19]); (b) net charge enzyme as a function of pH (adapted from Pihlasalo et al. [142]); topdown image shows the effect of several physical and biological agents responsible for denaturation with the respective target sites and the corresponding effects on enzymes.

structure of the enzyme to a disordered polypeptide in which key residues are no longer aligned closely enough to continue the participation in functional or structure stabilizing interactions [3]. If the denaturing influence is removed this tendency can be reversed. Enzymes must be formulated in order to maintain proper folding to perform their biological functions [10-12]. Their integrity under extreme conditions might involve high excipient concentrations [11] whose interactions are aided by several forces, such as hydrogen bonds, solvation forces, electrostatic, Van der Waal forces, amongst others [13-15]. These interactions can be controlled through screening of the charge by increasing the salt concentration of the solution or by changing the charge density on the surface $[16,17]$. Generally, at low ionic strength, the observed adsorption is to be maximumal at the isoelectric point [18], whereas the unfolding of the tertiary structure of protein reaches a maximum because of the large intramolecular electrostatic repulsion, as observed in Figure 1(a) $[19,20]$. The unfolding of the tertiary structure is greater at $\mathrm{pH} 11.5$ which is its isoelectric point (pl). Proteins have low solubility at $\mathrm{pl}$, because the effective charge of the molecule is zero (Figure 1(b)) and with decreased repulsion and electrostatic interaction between the molecules, they form clumps that tend to precipitate. In contrast, the adsorption efficiency decreases as $\mathrm{pH}$ increases, since the particles and protein repel each other due to repulsive charges, both having a negative charge [20,21].

The achievement of stable and active enzymes is often a challenging effort because they have not evolved naturally to be used in industrial environments. Their biological activity depends on the three-dimensional native structure, hence catalytically active, and any significant conformational change can lead to their inactivation [12]. Manifestations of enzyme instability arise from aggregation, loss of biological functionality, and exposure to extreme conditions or even slight variations of temperature or $\mathrm{pH}$, that can induce abrupt conformational changes and subsequent loss of their biological activity [22]. A number of enzyme-based processes have been commercialized for producing valuable products, however despite their great potential they have been hampered by undesirable stability, catalytic efficiency, and low specificity. For this reason, the exploitation of methodologies for enzyme stabilization is imperative for the progress in biotechnology and for potential protein-templates discovery (Figure 2).

Along this review, practical insights related with enzyme stabilization, highlighting experimental aspects for each methodology developed will be provide. This 


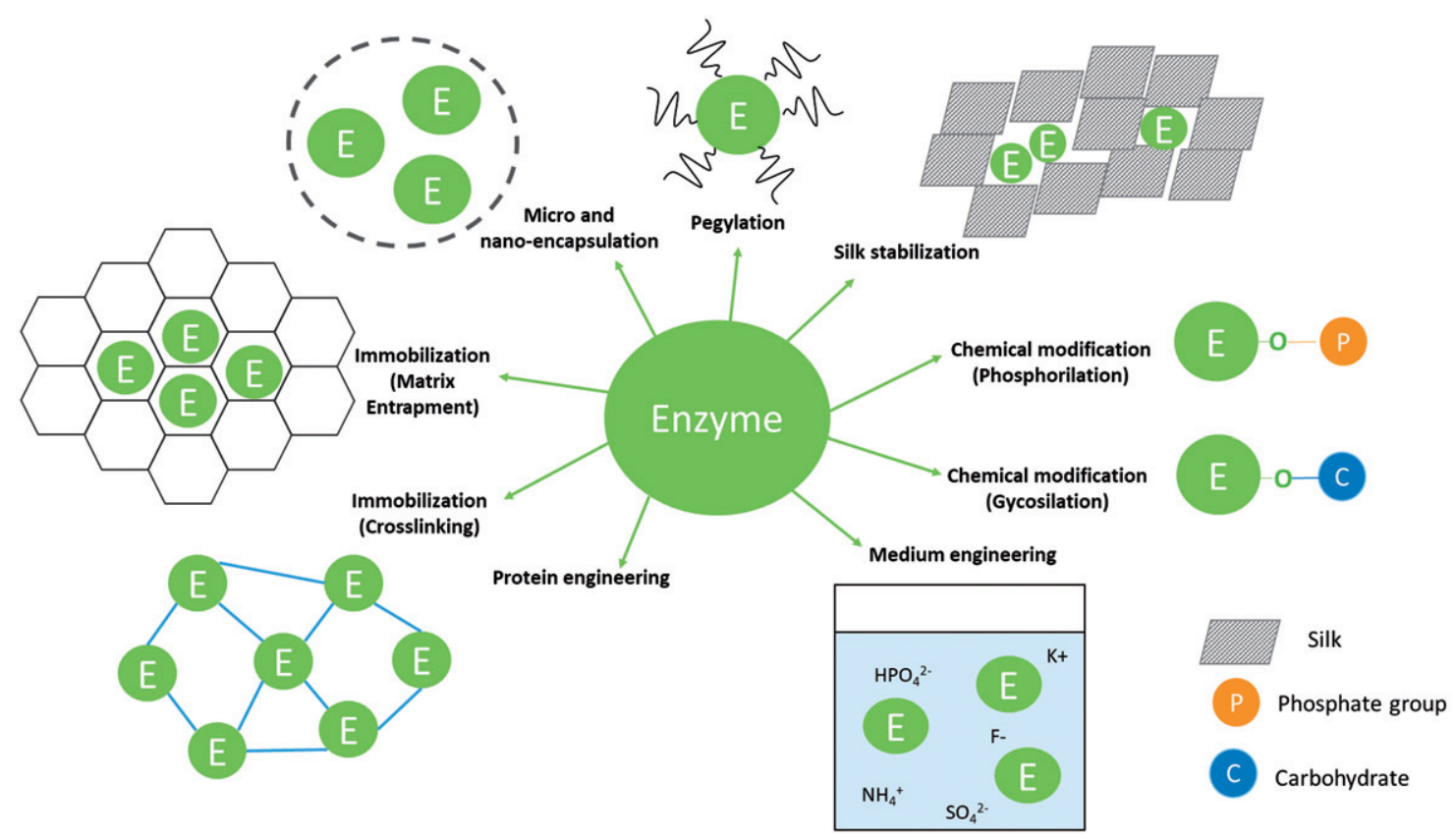

Figure 2. Schematic representation of different enzyme stabilization methodologies.

will be described along the text and practical examples will be specified in Table 1 .

\section{Enzyme-stabilization strategies}

\section{Screening and isolation of enzymes from extremophiles}

The interest in extremophiles stems from their surprising properties being superior to traditional catalysts and allowing the performance of industrial processes under harsh conditions in which conventional proteins are denaturated. There has been extensive research on the structural proteins and key metabolic enzymes that are responsible for the organisms' unusual properties. Recent research has focused on the identification of extremozymes relevant for industrial biocatalysis $[23,24]$.

Extremophiles are organisms that have evolved to exist in a variety of extreme environments and fall into a number of different classes that include thermophiles, acidophiles, alkalophiles, psychrophiles, and barophiles (piezophiles) and others. They can survive at high and low temperatures $\left(-5\right.$ to $\left.130^{\circ} \mathrm{C}\right)$, extreme $\mathrm{pH}(0-12)$, high salt concentrations (3-35\%), and high pressure (1000 bar). They have adapted to thrive in ecological niches such as deep-sea hydrothermal vents, hot springs, and sulfataric fields [25]. As a result, these microorganisms produce unique biocatalysts that function under conditions in which their mesophilic counterparts could not survive, permitting the development of additional industrial processes [24,25]. Many interesting enzyme classes that are active and stable under extreme conditions have been used to maximize reactions in the food and paper industry, detergents, drugs, toxic waste removal, and drilling for oil. These enzymes can be produced from the thermophiles through either optimized fermentation of the microorganisms or cloning of fast-growing mesophiles by recombinant DNA technology. It has been found that psychrophilic enzymes can assist enhance yield of heatsensitive products, halophilic enzymes that are stable in high salt concentrations serve as models for biocatalysis in low-water media and thermophilic enzymes that are highly resistant to proteases, detergents, and chaotropic agents, which may also afford resistance to the effects of organic solvents. Within these enzyme classes are included: esterases/lipases, glycosidases, aldolases, nitrilases/amidases, phosphatases, and racemases [24,25]. The most evident examples of the success of extremophiles, used in industrial large scale, are the starch degrading enzymes, $\alpha$-amylases [26]. Lipases and proteases, which are resistant to high temperatures, have also been the subject of study. In the textile industry, extremophilic enzymes find applications in several processes ranging from fiber preparation to finishing and subsequent laundering of textiles (see Table 1: Examples 1, 2, 3).

\section{Engineering of enzymes}

In the past, an enzyme-based process was designed around the limitations of the enzyme. Currently, the enzyme is engineered to fit process specifications [27]. 
Protein engineering is the design and construction of novel proteins, usually by manipulation of their genes. The rational protein design or direct evolution allows the alteration of enzyme properties to meet the limitations in their applications [28]. Rational design uses structural and mechanistic information together with molecular modeling for the prediction of changes in the protein structure in order to alter or induce the desired properties. Advances in computer technology have helped to create better protein models to improve predictions for rational design, but structure-activity relationships are still not trivial. In directed evolution, mutant libraries are created by random changes, screened for the desired property and the variants showing promising results are subjected to further rounds of evolution. More researchers today employ combined methods of these two strategies, called focused-directed evolution and semi-rational design $[29,30]$. The advances in genomics, proteomics, and informatics have been creating new opportunities to exploit a large amount of biological data [31-33].

The increased industrial requirements relate to the use of biocatalysts in aggressive non-natural media like organic solvents, ionic liquids, and physiologic fluids. This has led to the development of novel strategies to develop enzymes with improved performances [34]. Improving the activity of an industrial enzyme is often a primary goal. This is partly because naturally available enzymes are usually not optimally suited for many processes in industrial applications. Many enzymes used in the textile industry, such cellulases, amylases, lipases, and even proteases, act on insoluble substrates. Therefore, the rate of substrate turnover may be limited by diffusion, and controlled by enzyme mobility at the surface or by on/off enzyme desorption rates [35]. These, in turn, are often related to the surface properties of the enzyme and the conditions at the interface between the enzyme and substrate [36]. The experimental results from several site-directed variants with structural modeling of fungal lipase from Rhizopus oryzae have provided much insights into the molecular mechanism(s) of catalysis [36]. Substitutions at Glu87 and Trp89 in the lid region have been suggested to alter the activity of the lipase from Humicola lanuginosa (lipolase) [37]. Cellulases and xylanases have become a major focus in recent years due to their ability to provide the soft feel of stone-washed jeans in textile processing, fabric care benefits (such as color crispness) when used in laundry detergents [38], and reduction of the quantity of chemicals required for bleaching in the pulp and paper industry, thereby minimizing environmental impact [39]. Tyr169 in the Trichoderma reesei cellobiohydrolase II catalytic domain plays an important role in distorting the glucose ring into a more reactive conformation [40]. Some other relevant examples of enzyme engineering are given in this review in Table 1.

\section{Functionalization of enzymes}

Covalent chemical modification has emerged as a powerful alternative to site-directed mutagenesis and direct evolution for tailoring enzymes. Chemical modification of amino acid sidechains allows a greater, almost unlimited, variety of groups to be introduced, but the reactions used for their introduction are typically nonspecific in nature. Thus, despite many potential advantages, several classical methods used for protein modification create mixtures of proteins as a result of poor discrimination or insufficiently efficient chemistry [41].

A vast number of nonspecific modifications has been reviewed during the last decades. As examples, we highlight the introduction of hydrophobic and hydrophilic groups into chymotrypsin which stabilize the enzyme against thermal denaturation [42]. The nonspecific modification, as judged by 2,4,6-trinitrobenzenesulfonic acid (TNBS) titration, of amines in Candida rugosa lipase (CRL) with benzyloxycarbonyl (Z), Z- $\mathrm{NO}_{2}$, lauroyl, and acetyl-enhanced enantioselectivity in lipasecatalyzed esterification of 2-(4-substituted phenoxy)propanoic acids with $\mathrm{n}-\mathrm{BuOH}$ in isopropyl ether [43]. Phosphorylation, glycosylation, and farnesylation are also examples of enzyme modifications modulating their catalytic activity [44]. The chemical modification of cellulose by maleic anhydride and $\mathrm{N}$-bromosuccinimide was attempted to improve detergent stability [45].

Glutaraldehyde crosslinking and pegylation of enzymes surface have been other strategies to enhance biocatalyst stability [46]. The use of glutaraldehyde was firstly reported by Quiocho and Richards [47] and has triggered a series of improvements on highly stable CLECs (insoluble crosslinked enzyme crystals). This technology involves the crosslinking of enzyme microcrystals with bifunctional reagents, such as glutaraldehyde $[41,46,48]$. The behavior of several enzymes, normally used for textile finishing, modified by glutaraldehyde, such as the formation of dimers and higher oligomers and the production of enzymatic aggregates with preserved activity, was studied by Silva et al. [49] (see Table 1 for other examples).

Pegylation is a broadly used strategy characterized by the modification of a protein or peptide by the linking of one or more methoxy polyethylene glycol chains, a nontoxic and nonimmunogenic polymer. Pegylation changes the physical and chemical properties of the biomolecule, such as its conformation, electrostatic 
Table 1. Enzyme stabilization strategies (practical applications).

\begin{tabular}{|c|c|c|c|c|c|}
\hline Stabilization strategies & Enzyme & How to ... & Effect & Application & References \\
\hline \multirow{3}{*}{$\begin{array}{l}\text { Screening and isola- } \\
\text { tion of enzymes } \\
\text { from extremophiles }\end{array}$} & Amylase & $\begin{array}{l}\text { Acidophile, thermophile and } \\
\text { psychrophile/ }\end{array}$ & Increase oxidative stability & Desizing of cotton & {$[116,117]$} \\
\hline & Protease & $\begin{array}{l}\text { Thermophile, psychrophile, } \\
\text { halophile, alkaliphile }\end{array}$ & $\begin{array}{l}\text { Shrinkage reduction; } \\
\text { improved dyeability }\end{array}$ & $\begin{array}{l}\text { Degumming of silk and } \\
\text { production of sand wash } \\
\text { effect }\end{array}$ & {$[118-121,123]$} \\
\hline & Esterase & Thermophile & $\begin{array}{l}\text { Depilling and improvement } \\
\text { of dyeing of polyester } \\
\text { fibers }\end{array}$ & $\begin{array}{l}\text { Polyester hydrolysis and } \\
\text { depolymerization; ring- } \\
\text { open polymerization }\end{array}$ & [112-125] \\
\hline \multirow[t]{5}{*}{$\begin{array}{l}\text { Engineering of } \\
\text { enzymes }\end{array}$} & Cutinase & $\begin{array}{l}\text { Fusion of cutinase with two } \\
\text { CBM (cellulose-binding } \\
\text { models) }\end{array}$ & $\begin{array}{l}\text { Modify acetate cellulose } \\
\text { fibers and increase } \\
\text { hydrophilicity }\end{array}$ & $\begin{array}{l}\text { Surface modification of } \\
\text { acetate cellulose fibers }\end{array}$ & [126] \\
\hline & Cutinase & $\begin{array}{l}\text { Genetic modification by site- } \\
\text { directed mutagenesis }\end{array}$ & $\begin{array}{l}\text { Enhance activity towards } \\
\text { synthetic fibers (polyester } \\
\text { and polyamide) }\end{array}$ & Synthetic fibers modification & [127] \\
\hline & Protease & $\begin{array}{l}\text { Construction of a recombin- } \\
\text { ant protein with subtilisin } \\
E \text { and elastin-like polymer }\end{array}$ & $\begin{array}{l}\text { Increase the molecular } \\
\text { weight of subtilisin E to } \\
\text { use as alternative to } \\
\text { chlorine treatment of } \\
\text { wool }\end{array}$ & $\begin{array}{l}\text { Alternative method to chlor- } \\
\text { ine treatment of wool }\end{array}$ & [121] \\
\hline & Laccase & $\begin{array}{l}\text { Site-directed mutagenesis in } \\
\text { four phenylalanine near } \\
\text { the active site }\end{array}$ & $\begin{array}{l}\text { Increase oxidation of } \\
\text { phenolics }\end{array}$ & $\begin{array}{l}\text { Phenolics oxidation for poly- } \\
\text { merization; textile waste } \\
\text { water treatment }\end{array}$ & [128] \\
\hline & Xylanase XT6 & $\begin{array}{l}\text { Directed evolution and site- } \\
\text { directed mutagenesis }\end{array}$ & $\begin{array}{l}52 \times \text { increase in thermal sta- } \\
\text { bility; } K_{\text {opt }} \text { increase by } 10^{\circ} \mathrm{C} ; \\
\text { catalytic efficiency increase } \\
\text { by } 90 \%\end{array}$ & Biobleaching & [129] \\
\hline \multirow[t]{2}{*}{$\begin{array}{l}\text { Functionalization of } \\
\text { enzymes }\end{array}$} & Laccase & $\begin{array}{l}\text { PEGylation of laccase with } \\
\text { mPEG in presence of } \\
\text { cianoborohydride }\end{array}$ & $\begin{array}{l}\text { Improve stability and cata- } \\
\text { lytic activity }\end{array}$ & $\begin{array}{l}\text { Polymerization of phenolics; } \\
\text { bioremediation }\end{array}$ & [50] \\
\hline & Glucose-oxidase & $\begin{array}{l}\text { PEGylation of GOx followed } \\
\text { by controlled chemical } \\
\text { modification with } \\
\text { glutaraldehyde }\end{array}$ & $\begin{array}{l}\text { Using this stabilization strat- } \\
\text { egy, size increases and } \\
\text { aggregation due to inter- } \\
\text { molecular crosslinking are } \\
\text { avoided; PEGylated } \\
\text { enzyme retains } 73 \% \text { ori- } \\
\text { ginal activity after } 4 \\
\text { weeks at } 37^{\circ} \mathrm{C} \text { (vs. } 8.2 \% \\
\text { retention for control). }\end{array}$ & $\begin{array}{l}\text { Enzymatic bleaching of cot- } \\
\text { ton; hydrogen peroxide } \\
\text { generation }\end{array}$ & [54] \\
\hline \multirow[t]{6}{*}{$\begin{array}{l}\text { Immobilization of } \\
\text { enzymes }\end{array}$} & $\alpha$-amylase & $\begin{array}{l}\text { Chemical cross-linking of } \\
\text { enzyme aggregates with } \\
\text { amino functionalized } \\
\text { magnetite nanoparticles } \\
\text { (CLEAs) }\end{array}$ & $\begin{array}{l}\text { Enhance thermal and stor- } \\
\text { age stability; Free } \\
\text { enzyme: } \\
K_{\mathrm{m}}=0.93 \pm 0.014 \\
V_{\max }=85 \pm 0.11 ; \text { mag- } \\
\text { netic CLEAs: } \\
K_{\mathrm{m}}=0.21 \pm 0.019 \\
V_{\max }=81 \pm 0.27\end{array}$ & Desizing of cotton & [61] \\
\hline & $\beta$-glucosidase & $\begin{array}{l}\text { Covalent immobilization of } \\
\beta-1,4-\text { glucosidase from } \\
\text { Agaricus arvensis onto } \\
\text { functionalized silicon } \\
\text { oxide nanoparticles }\end{array}$ & 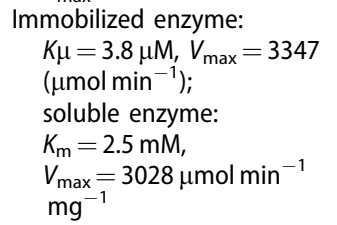 & Lignocellulose hydrolysis & [130] \\
\hline & Laccase & $\begin{array}{l}\text { Laccase formulation was } \\
\text { immobilized on modified } \\
\text { green coconut fiber silan- } \\
\text { ized with 3-glycidoxypro- } \\
\text { pyltrimethoxysilane }\end{array}$ & $\begin{array}{l}\text { Increase affinity and activity } \\
\text { to the substrate }\end{array}$ & $\begin{array}{l}\text { Textile waste water } \\
\text { treatment }\end{array}$ & [131] \\
\hline & Protease & $\begin{array}{l}\text { Esperase, was covalently } \\
\text { linked to Eudragit S-100, } \\
\text { a reversible soluble-insol- } \\
\text { uble polymer by carbodii- } \\
\text { mide coupling }\end{array}$ & Increase thermal stability & $\begin{array}{l}\text { Wool shrink-resist finish } \\
\text { of wool }\end{array}$ & [132] \\
\hline & Laccase & $\begin{array}{l}\text { Laccase was immobilized } \\
\text { onto polyamide } 6.6 \text { fibers }\end{array}$ & $\begin{array}{l}\text { Increase stability on textile } \\
\text { surfaces }\end{array}$ & Waste water treatment & [133] \\
\hline & $\begin{array}{l}\text { Candida antarctica } \\
\text { lipase B (CALB) }\end{array}$ & $\begin{array}{l}\text { Immobilization on macropo- } \\
\text { rous resin of poly(methyl } \\
\text { methacrylate }\end{array}$ & $\begin{array}{l}\text { Catalyze organic chemical } \\
\text { reactions }\end{array}$ & $\begin{array}{l}\text { Polyester synthesis by ring- } \\
\text { opening polymerization } \\
\text { of various lactones and } \\
\text { polycondensation reac- } \\
\text { tions of diacid/diol } \\
\text { substrates }\end{array}$ & [134] \\
\hline
\end{tabular}


Table 1. Continued

\begin{tabular}{|c|c|c|c|c|c|}
\hline Stabilization strategies & Enzyme & How to ... & Effect & Application & References \\
\hline & $\begin{array}{l}\text { Cutinase from } \\
\quad \text { Fusarium solani }\end{array}$ & $\begin{array}{l}\text { Immobilization of cutinase } \\
\text { on ewatit } \\
\text { Beads or in the form of } \\
\text { cross-linked enzyme } \\
\text { aggregates (CLEA) }\end{array}$ & $\begin{array}{l}\text { Catalyze organic chemical } \\
\text { reactions }\end{array}$ & Synthesis of polyamides & [135] \\
\hline \multirow[t]{3}{*}{ Medium engineering } & Ribonuclease & $\begin{array}{l}\text { Addition of sucrose, trehal- } \\
\text { ose, glucose, maltose and } \\
\text { ribose to enzyme } \\
\text { formulations }\end{array}$ & Increase stabilization & - & [66] \\
\hline & Lysozyme & $\begin{array}{l}\text { Addition of PEG mixed } \\
\text { solvents }\end{array}$ & $\begin{array}{l}\text { Increase solubility and } \\
\text { stability }\end{array}$ & - & [92] \\
\hline & Protease & $\begin{array}{l}\text { Addition of pyridinium and } \\
\text { imidazolium-based ionic } \\
\text { liquids }\end{array}$ & $\begin{array}{l}\text { Stabilization by kosmotropic } \\
\text { anions and destabilization } \\
\text { by chaotropic anions; } \\
\text { Hofmeister series in } \\
\text { general }\end{array}$ & $\begin{array}{l}\text { Food industry; wool } \\
\text { finishing }\end{array}$ & [136] \\
\hline \multirow[t]{3}{*}{ Enzyme encapsulation } & Laccase & $\begin{array}{l}\text { Encapsulation into in } \\
\text { liposomes }\end{array}$ & Increase stability & Textiles and cosmetics & [137] \\
\hline & Amylase & $\begin{array}{l}\text { Encapsulation into magnetic } \\
\text { chitosan beads }\end{array}$ & Increase stability & Food industry & [138] \\
\hline & Laccase & $\begin{array}{l}\text { Encapsulation in oil-in-water } \\
\text { proteinaceous micro- } \\
\text { emulsions }\end{array}$ & $\begin{array}{l}\text { Increase enzyme stability at } \\
\text { high temperatures and } \\
\text { high shear stress }\end{array}$ & Textile and cosmetics & [139] \\
\hline \multirow[t]{2}{*}{$\begin{array}{l}\text { Enzyme stabilization } \\
\text { by silk }\end{array}$} & Lipase & $\begin{array}{l}\text { Study the stability of lipase } \\
\text { on both water-soluble } \\
\text { and insoluble silk fibroin } \\
\text { films }\end{array}$ & $\begin{array}{l}\text { Increase enzyme stability at } \\
37^{\circ} \mathrm{C} \text { without need to } \\
\text { use cryoprotectantes, } \\
\text { emulsifiers or covalent } \\
\text { immobilization }\end{array}$ & Lipid hydrolysis & [140] \\
\hline & Glucose-oxidase & $\begin{array}{l}\text { GOx immobilized in air dried } \\
\text { silk films }\end{array}$ & Improved enzyme activity & $\begin{array}{l}\text { Ampometric sensors for glu- } \\
\text { cose detection }\end{array}$ & [141] \\
\hline
\end{tabular}

binding, size, and hydrophobicity, improving the catalytic behavior of enzymes and their stability in aqueous media. The greatly expanded hydrodynamic volume of the PEG-enzyme conjugate resulting from mPEG ability to coordinate water molecules can be responsible for these changes [50,51]. Despite being explored mainly in the pharmaceutical area, this technique has been extended to other areas for the modification and stabilization of a broad range of enzymes. Examples of succeeded enzyme pegylation are presented in Table 1.

\section{Immobilization of enzymes}

Enzymes are generally expensive and unlike conventional heterogeneous chemical catalysts, most of them operate dissolved in water in homogeneous catalysis systems, leading to product contamination and ruling out their recovery and reuse [52]. One of the most used strategies to overcome these drawbacks is immobilization. It is a technical process in which enzymes are fixed to or within solid supports, creating a heterogeneous immobilized enzyme system [52]. The solid support stabilizes the enzyme structure maintaining its activity.

Approaches used for the design of immobilized enzymes include a variety of methods: adsorption, covalent binding, entrapment with nanofibrous polymers, nanoparticles, cross-linked enzyme aggregates, or crystals [53]. Support binding can be physical or chemical, involving weak or covalent bonds. Physical bonding is weak and hardly able to keep the enzyme fixed to the carrier under industrial conditions. The support can be a synthetic resin, an inorganic polymer such as zeolite or silica, or a biopolymer. Entrapment involves inclusion of an enzyme in a polymer network such as an organic polymer or silica-gel, or a membrane device such as a hollow fiber or a microcapsule. It requires the synthesis of the polymeric network in the presence of the enzyme. The covalent attachment involves the cross-linking of enzyme aggregates or crystals, using a bifunctional reagent, to prepare carrier-free macroparticles $[52,53]$. The ideal immobilization procedure for a given enzyme is the one that allows a high turnover rate of the enzyme while retaining high catalytic activity over time. Recently, the major focus of enzyme immobilization is the development of robust enzymes that are not only active but also stable and selective in organic solvents. Moreover, several new types of carriers and technologies have been implemented which aimed to enhance enzyme loading, activity, and stability decreasing though the biocatalyst cost in industrial applications [52,54-56]. These include: cross-linked enzyme aggregates, microwave-assisted immobilization, click chemistry technology, mesoporous supports, and nanoparticle-based immobilization. The high surface-tovolume ratio offered by nanoparticles resulted in the 
concentration of the immobilized entity being higher than that afforded by 2-D surface protocols [55].

Enzyme immobilization envisage between other goals, to increase the activity of the catalyst. The enhancement of enzyme activity upon immobilization depends on: the microenvironment, partition effect, diffusion effect, conformational change, molecular orientation, conformational flexibility, conformation induction, and binding mode. It has been observed that many immobilized enzymes exhibit higher activity than the corresponding native enzyme [57-59] and only few reports about the decrease of $K_{\mathrm{m}}$ and increase $V_{\max }$ upon formation of crosslinked enzyme aggregates (CLEAs) $[60,61]$ (see Table 1 for other examples related with enzyme immobilization on textile, bioremediation industries, and polymer synthesis).

\section{Medium engineering}

Enzymes for industrial purposes are sold on the basis of the overall activity. The manufacturer will usually recommend storage conditions and quote the expected rate of activity loss under those conditions. It is of primary importance to the enzyme producer and customer that the enzymes retain their activity during storage and use. Some enzymes retain their activity under operational conditions for weeks or even months but others do not. Excipients are required to increase the longterm stability of enzymes following processing and storage [62]. Moreover, despite enzymes are recognized by their several advantages has biocatalysts, like biodegradability, high specificity, and activity under mild conditions, they fail for most reactions when water is not the preferable solvent. For this, enzymes must be tolerant to the presence of organics and the medium engineering by addition of inorganic salts, polyols, and sugars to the enzyme aqueous solution seems to be an efficient approach $[62,63]$.

The structural stability of enzymes is controlled by the interactions between protein molecules and the surrounding solvent molecules [63]. Changes in the microenvironment of the biocatalyst not only are able to modulate the enzyme activity and stability but also to shape the enzyme selectivity. One of the main variables in biotransformations is the water content in the enzyme microenvironment. The water activity is relevant since it involves the effect of water mass action on the chemical equilibrium [64]. Besides, the role of water is complex and diverse, since water is able to participate directly as a substrate, and/or during the transition states and/or as reaction product. Moreover, water can take part in the reaction not only directly, but in an equally relevant role as a "'lubricant"', providing solvation to polar residues of the biocatalyst and other intervening molecules in order to facilitate protein conformational changes during the biocatalytic process and to speed up the reaction. There are many different approaches to control water activity in biotransformations, but the control of media composition is the simplest one.

\section{The role of solvents}

Solvents can be categorized as: water-miscible (monophasic aqueous-organic systems, including some ionic liquid systems), non-aqueous (monophasic organic system), water-immiscible (multiphasic aqueous-organic systems, and most of ionic liquid systems described to date), anhydrous systems (including solvent free systems), supercritical fluids and gas phase, and reversed micelles. The effects of polar and non-polar solvents on enzyme activity are quite dissimilar; both reduce the enzyme activity for different reasons. In polar solvents, water stripping is the major, but not the only reason for reduction of enzyme activity. Water stripping is referred to the ability of polar organic solvents to displace water molecules from the protein surface, to be replaced by solvent molecules which rigidify the molecular structure of the enzyme and concomitantly affects the enzyme turn-over [64]. Additionally, polar solvents can interfere with the ionic interactions of the protein and/or breaking polar interactions which induce at least a partial unfolding of the molecular structure, especially in enzymes with polar/dipolar transitions states and intermediates. High conversion efficiency in non-aqueous homogeneous biocatalysis can be achieved only with high enzyme solubility and stability in the water-organic mixture.

\section{Polyols, sugars, and salt addition (/ionic liquids)}

Addition of polyols and sugars to aqueous solutions of proteins promotes strengthening of the hydrophobic interactions among non-polar amino acid residues, leading to protein rigidification and enhancing thermostability [63]. Moreover, it has been postulated that the effect of polyols on the activity of water seems to govern their stabilization effect. Some theories state that the protective effect of sugars against destabilization when added to the medium replace water molecules that are removed from the hydration shells of the proteins [63,65-68] (Figure 3). Other hypothesis postulate that the protective moieties are excluded from the surfaces of the protein entities and thus the available water molecules in solution can interact with the protein entity, stabilizing its native configuration. Due to the preferential exclusion of the protective sugar moieties from the 


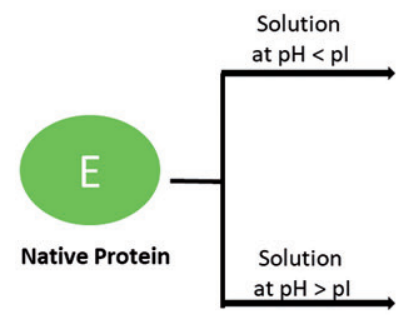

(immediate domain) hydration shell of protein entities, sugar moieties shape a protective and stabilizing shield around those biomolecules. The basis of this phenomenon is the difference in size between molecules of water and those of the sugar moieties. Essentially, a shell is formed around the protein at the radius of closest approach between the protein and the sugar moiety, a shell that is impenetrable to the sugar moieties but is penetrable to water, resulting in an excess of water in the vicinity of the protein: preferential hydration. Preferential hydration of proteins is favored due to stronger interactions between sugar and water molecules compared to those between sugar and protein molecules [69-71]. Such preferential exclusion increases the chemical potential of the protein molecule $[69,72-75]$, proportionally to the solvent exposed surface area. According to the Le Chatelier's principle, sugar osmolytes favor the more compact state (viz, the native, folded state, $F$ ) over the structurally expanded state (viz. the unfolded, denatured state, $U$ ), which leads to an increase of the Gibbs free energy change associated with the denaturation process $(F \Longleftrightarrow U$ ) in the presence of osmolytes (one should remember at this point that $\Delta G D=-R T \ln ([U] /[F]))[72,76-79]$.

In general, enzymes are stabilized by increasing their concentration and the ionic strength of the environment. Neutral salts compete with enzymes for water and bind to charged groups or dipoles. This may result in the interactions between enzyme's hydrophobic areas being strengthened and causing the enzyme molecules to compress and making them more resistant to thermal unfolding reactions. Not all salts are equally effective in stabilizing hydrophobic interactions, some are much more effective at their destabilization by binding to them and disrupting the localized structure of water (the chaotropic effect). From this, it can be seen why ammonium sulfate and potassium hydrogen phosphate are a powerful enzyme stabilizers whereas sodium thiosulfate and calcium chloride destabilize enzymes. Many enzymes are specifically stabilized by low concentrations of cations which may or may not form part of the active site, for example $\mathrm{Ca}^{2+}$ stabilizes $\alpha$-amylases and $\mathrm{Co}^{2+}$ stabilizes glucose isomerases. At high concentrations (e.g. $20 \% \mathrm{NaCl}$ ), salt discourages microbial growth due to its osmotic effect. In addition, ions can offer some protection against oxidation to groups such as thiols by salting-out the dissolved oxygen from solution. The stabilization property of these efficient salts is governed by a competition phenomenon between salt exclusion and salt binding effects. These salts increase the surface tension at waterenzyme interface and strengthen hydrophobic interactions by keeping hydrophobic moieties away from water molecules [80-83]. Dissolved salts in aqueous solutions have a strong influence on protein-protein interactions and on the aggregates formed. The effect of salts on protein solubility and stability have been known for more than a century and were first reported by Franz Hofmeister [84]. A variety of inorganic ions has been tested for their ability to precipitate various proteins from solution. The overall order of a particular anion's and cation's effectiveness as a protein precipitant is generally as follows:

$$
\begin{aligned}
& \mathrm{CO}_{3}{ }^{2-}>\mathrm{SO}_{4}{ }^{2-}>\mathrm{S}_{2} \mathrm{O}_{3}{ }^{2-}>\mathrm{H}_{2} \mathrm{PO}^{4-}>\mathrm{F}^{-}>\mathrm{Cl}^{-} \\
& >\mathrm{Br}^{-}>\mathrm{NO}^{3-}>\mathrm{I}^{-}>\mathrm{ClO}_{4}{ }^{-}>\mathrm{SCN}^{-} \\
& \mathrm{N}\left(\mathrm{CH}_{3}\right)_{4}^{+}>\mathrm{NH}_{4}^{+}>\mathrm{Cs}^{+}>\mathrm{Rb}^{+}>\mathrm{K}^{+}>\mathrm{Na}^{+}>\mathrm{Li}^{+} \\
& \quad>\mathrm{Ca}^{2+}>\mathrm{Mg}^{2+}
\end{aligned}
$$


Anions to the left of chloride are well hydrated and help salt proteins out of solution. Anions to the right of chloride generally salt proteins into solution and are more weakly hydrated. The salting-out anions have a higher charge-to-volume ratio and generally have fairly weak polarizabilities [84]. Work conducted on lysozyme provided evidence that above protein isoelectric point, the macromolecule bears a negative charge, and a direct Hofmeister series is observed. Chaotropes like $\mathrm{I}^{-}$, $\mathrm{ClO}_{4}{ }^{-}$, and $\mathrm{SCN}^{-}$help to unfold proteins and salt them into solution. Kosmotropes, like $\mathrm{SO}_{4}{ }^{2-}$ and $\mathrm{F}^{-}$, lead to the stabilization of the folded state and cause a saltingout effect. If the $\mathrm{pH}$ of the solution is below $\mathrm{pl}$ of the protein, the macromolecules are net positively charged and an inverse Hofmeister series is observed. Chaotropic anions become more effective at salting-out proteins from solution than kosmotropic anions $[85,86]$ (see Table 1 for other examples).

lonic liquids are eco-friendly solvent media which play an important role in several enzymatic reactions [87]. ILs are composed of an organic cation involving imidazolium, pyrrolidinium, pyridinium, ammonium, quanidinium, and other cations with a variety of substituents and an organic anion (halides, tetrafluoroborate, hexa fluorophosphates, and larger anions containing sulfonynol or fluoroalkyl groups) [87]. ILs have many favorable properties such as low vapor pressure, a wide liquid range, low flammability, high ionic conductivity, high thermal conductivity, high dissolution capability toward many substrates, high thermal and chemical stability, and a wide electrochemical potential window $[88,89]$. Because of these unique properties, ILs have been widely recognized as solvents or (co-)catalysts in a variety of applications including organic catalysis, inorganic synthesis, biocatalysis, polymerization, and engineering fluids. Typical IL cations are nitrogen-containing (such as alkylammonium, $N, N^{\prime}$-diaIkylimidazolium, $\mathrm{N}$-alkylpyridinium, and pyrrolidinium), or phosphorous-containing (such as alkylphosphonium). The common choices of anions include halides, $\mathrm{BF}_{4}^{-}$, $\mathrm{PF}_{6}^{-}, \mathrm{CH}_{3} \mathrm{CO}_{2}^{-}, \mathrm{CF}_{3} \mathrm{CO}_{2}^{-}, \mathrm{NO}_{3}^{-}, \mathrm{Tf}_{2} \mathrm{~N}^{-},\left[\left(\mathrm{CF}_{3} \mathrm{SO}_{2}\right) 2 \mathrm{~N}^{-}\right]$, $\left[\mathrm{RSO}_{4}\right]^{-}$, and $\left[\mathrm{RPO}_{4}\right]^{-}[88]$.

It has been postulated that some ILs properties, such as polarity, hydrogen-bond basicity, and nucleophilicity of anions, Hofmeister series, hydrophobicity, and viscosity, influence greatly the enzyme's catalytic behavior [90]. Imidazolium ILs can form $\mathrm{H}$-bonded polymeric supramolecules, so-called organized nanostructures with polar and non-polar regions responsible for enzyme stabilization; many ILs contain hydrophilic and lipophilic segments which turn them amphiphilic and behaving as surfactants forming aggregates and micelles; due to their hydrophobic nature, the alkyl chains of organic cations in aqueous solutions are surrounded by water molecules forming "cage-like" structures so-called "hydrophobic hydration"; the inclusion of other molecules and macromolecules into the polymeric IL network results in the formation of polar and non-polar regions; the aqueous solution of free enzyme can be surrounded by the IL network retaining its activity [91]. A considerable number of enzymes are not soluble in most common ILs, being suspended in the reaction media with low water content. Thus, the network theory is not sufficient to explain the enzyme stabilization by the ILs [91]. The impact of individual ions must also be considered. The effect of ILs aqueous solutions on enzyme activity follows the ion kosmotropicity (Hofmeister series): kosmotropic anions and chaotropic cations stabilize the enzyme, while chaotropic anions and kosmotropic cations destabilize (see examples in Table 1).

\section{Polymers and surfactants}

The stabilizing effect of polymers addition to enzyme formulations may promote the exclusion of protein molecules from part of the solvent and prevent detrimental effects of the environment upon the enzyme molecules. By the inclusion of PEG, one of the most used stabilizing polymers, protein molecules became hydrated, explained by a steric (hindrance) exclusion mechanism due to large difference in sizes between water and PEG molecules, with PEG being excluded from enzyme vicinity $[63,92]$.

Enzyme-contained in a reverse micellar system is also a feasible strategy for enzyme stabilization [93]. The reversed micelle is formed by surfactant amphiphiles self-aggregated in the bulk apolar organic solvents. The surfactant molecules assemble themselves with the polar head to the inner side and the apolar tail in contact with the organic solvent. This self-aggregation only occurs when the surfactant concentration is above the critical micelle concentration (CMC). Because of the formed polar cores, reversed micellar system allows nanometer-sized aqueous droplets stabilized in it. The process of enzyme solubilization in reversed micelles results in the formation of enzyme-containing reversed micellar system, and the entrapped enzymes have enhanced activities under those conditions as suited in the lipid bilayers of biological membranes [93]. The surfactant concentration influences greatly the enzyme solubilization and its catalytic efficiency. Some works reported the decrease of catalytic activity with the increase of surfactant concentration in the organic solvent [94]. 


\section{Storage stabilization of enzymes}

Enzymes are generally best stored at $\leq 4^{\circ} \mathrm{C}$ in clean, autoclaved glassware or polypropylene tubes. Storage at room temperature often leads to protein degradation and/or inactivity, commonly as a result of microbial growth. For short-term storage (1 day to a few weeks), many proteins may be stored in simple buffers at $4{ }^{\circ} \mathrm{C}$. For long-term storage for 1 month to 1 year, some researchers choose to bead single-use aliquots of the protein in liquid nitrogen for storage in clean plastic containers under liquid nitrogen. This method involves adding the protein solution dropwise (about $100 \mu \mathrm{l}$ each) into a pool of liquid nitrogen, then collecting the drop-sized frozen beads and storing them in cryovials under liquid nitrogen.

Frozen at $-20^{\circ} \mathrm{C}$ or $-80^{\circ} \mathrm{C}$ is the more common form of cold protein storage. Because freeze-thaw cycles decrease protein stability, samples for frozen storage are best dispensed and prepared in single-use aliquots so that, once thawed, the protein solution will not have to be refrozen. Alternatively, addition of 50\% glycerol, ethylene glycol, or DMSO will prevent solutions from freezing at $-20^{\circ} \mathrm{C}$, enabling repeated use from a single stock without warming (i.e. thawing). These inert substances modify the physicochemical properties of aqueous solutions. They are preferentially excluded from contact with the protein surface, being the protein molecule hydrated, thus accounting their protective effect [63].

Dilute protein solutions $(<1 \mathrm{mg} / \mathrm{ml})$ are more prone to inactivation and activity loss as a result of low-level binding to the storage vessel. Therefore, it is common practice to add "carrier" or "filler" protein, such as purified bovine serum albumin (BSA) to $1-5 \mathrm{mg} / \mathrm{ml}$ $(0.1-0.5 \%)$, to dilute protein solutions to protect them against such degradation and loss. Many compounds may be added to enzyme solutions to lengthen shelf life, namely cryoprotectants such as glycerol or ethylene glycol to stabilize proteins by preventing the formation of ice crystals at $-20^{\circ} \mathrm{C}$ that destroy the protein structure; protease inhibitors to prevent proteolytic cleavage of proteins; anti-microbial agents such as sodium azide $\left(\mathrm{NaN}_{3}\right)$ to inhibit microbial growth; metal chelators such as EDTA to avoid metal-induced oxidation of -SH groups and help to maintain the protein in a reduced state; reducing agents such a dithiothreitol (DTT) and 2mercaptoethanol (2-ME) to maintain the protein in the reduced state by preventing oxidation of cysteines [95].

\section{Enzyme encapsulation}

The encapsulation of enzymes contemplates the entrapment in a polymer network (gel lattice), in a silica sol- gel, in a membrane device or in a microcapsule. The entrapment requires the synthesis of a polymeric network in the presence of the enzyme to be encapsulated [96]. Nanoparticles have been used as enzyme immobilization carriers [97]. Enzymes immobilized onto nanosized scaffolds like spheres, fibers, and tubes have been reported [98]. Effective enzyme loading on nanoparticles has been achieved for up to $10 \mathrm{wt} \%$ due to a large surface area per unit mass of nanoparticles. Overall, nanoparticles are considered to be an ideal support for enzyme immobilization due to their minimized diffusional limitations, maximum surface area per unit mass, and high enzyme loading capability [98]. Theoretical and experimental studies have demonstrated that particle mobility, which is governed by particle size and solution viscosity, can impact the intrinsic activity of the particle-attached enzymes [97].

One of the most studied templates for enzyme immobilization is the encapsulation in silica matrices. Studies on the immobilization of enzymes within biosilica nanoparticles formed by reaction of a silicate precursor with a silica-precipitating peptide, demonstrated that the reaction rapidly formed a network of fused silica nanospheres that entrapped the peptide [99]. These nanodevices have been explored and demonstrated several advantages compared with other encapsulation methods. They are inexpensive, no need for chemical reagents for synthesis, the immobilization occurs in seconds, the particles formation is done at mild conditions, the matrix can be dissolved to release the entrapped enzyme and have a high level of stabilization uptake [98].

Most techniques for obtaining nanoparticles that contain enzymes have been based on the so-called "nanoentrapment" approach using the water-in-oil microemulsion system (also called reverse micelles), which leads to discrete nanoparticles through polymerization in the water phase or water-oil interface [100]. Within these nanodevices the size and the number of enzyme molecules within a reverse micelle is difficult to control. To overcome this, a new synthetic approach was reported under the name of "single enzyme nanoparticles (SENs)", in which an organic-inorganic hybrid polymer network of a thickness of less than a few nanometers was built up from the surface of the enzyme. This approach is therefore in stark contrast to the conventional nanoentrapment described above. SEN synthesis consists of three steps: (i) the enzyme surface is modified in water by acryloylation; (ii) the vinyl polymer is grown from the enzyme surface in hexane; and (iii) the attached polymer chains undergo orthogonal polymerization via silanol condensation crosslinking [100]. SENs constitute a new approach in industrial enzyme research [101,102]. The SEN form means that every 
single enzyme molecule is surrounded with a porous polymer matrix layer on a nanometer scale, resulting in higher stability of the enzyme without any significant limitation to mass transfer of the substrate from solution to the active site. Individual magnetic enzyme nanoparticles were produced by Yang et al. (2008) via surface modification and aqueous polymerization of each separate enzyme molecule. Their results show that the stability of the enzyme and organic/inorganic network composites is retained over a wide $\mathrm{pH}$ range $(\mathrm{pH}=5.5-9.0)$ and at high temperatures $\left(60-70^{\circ} \mathrm{C}\right)$ in organic solvents [103].

One-dimensional nanostructured materials such as fibers, wires, rods, belts, tubes, spirals, and rings have attracted the interest for enzyme encapsulation. Electrospun nanofibers are simple and most used for this purpose. They are long, uniform in diameter, and can be diversified in composition [96].

The enzyme encapsulation into liposomes is a promising strategy to stabilize and prevent denaturation. By controlling lipid membrane permeability it is possible to control the permeability of liposomes increasing the permeation of the substrate. These devices allow the stabilization of and succeed to maintain the full enzyme function [104].

Enzyme immobilization is an important strategy to enhance the stability and recoverability of enzymes and to facilitate the separation of enzymes from reaction products. However, enzyme purification followed by separate chemical steps to allow immobilization on a solid support reduces the efficiency and yield of the active enzyme

Strategies that use enzymes as a buildingblock for biomaterials have been developed to overcome some drawbacks related with enzyme purification and chemical separation. Recently, Zhou and coworkers described polypeptide constructs that self-assemble spontaneously into nanofibrils with fused active enzyme subunits displayed on the amyloid fibril surface. They showed that the fibrils can be recycled and reused in functional assays both in conventional batch processes and in a continuous-flow microreactor [105]. They also developed enzymatically active microgels that are stabilized by amyloid nanofibrils [106]. The protein nanofibrils were also applied to generate colloidosome-like two-dimensional crosslinked networks of nanostructures templated by all-aqueous emulsions, which were nominated as fibrillosomes [107].

\section{Enzyme stabilization by silk}

Silk fibroin is a biologically derived protein from domesticated silkworm cocoons and is a material with great potential for the immobilization and preservation of enzymes [108]. The mechanisms underlying enzyme stabilization by silk fibers can be divided in two groups: mechanisms of stabilization in the liquid state and solid states. In the liquid state, preferential exclusion, where silk fibroin is characterized by its steric exclusion ability on proteins solution, and hydrophobic and electrostatic binding. The later effect is explained by the silk's amphiphilic nature, allowing for shielding of exposed hydrophobic patches, by the high degree of hydrophobicity and by its high charge which by interaction with protein surroundings can alter the exposed surface charge distribution, changing the protein-protein interaction [108]. In the solid state, the mechanisms of stabilization are related with the water replacement hypothesis and glass dynamics or vitrification hypothesis [108].

\section{Major remarks and future perspectives}

Enzyme stabilization does not end on the methodologies described during discussion, it is important to note that there are procedures wherein diverse stabilization methods have been applied simultaneously or consecutively to afford the best stabilization conditions, higher yield, and recovery of the support material after enzyme inactivation [3].

Examples have been discussed: (i) the case of sitedirected mutagenesis of penicillin $G$ acylase from Escherichia coli for better immobilization [109], (ii) immobilization followed by modification of penicillin acylase with aldehyde-dextran [110], (iii) multipoint covalent attachment of penicillin acylase and later entrapping the enzyme into a hyperhydrophilic nanoenvironment [111], (iv) PEG-ylation and subsequent immobilization of creatinine amidohydrolase for biosensor development [112], (v) site-directed mutagenesis of thermolysin-like neutral protease from Bacillus stearothermophilus followed by immobilization [113], (vi) use of stabilizing additives in combination with covalently immobilized a-chymotrypsin [114], and (vii) chemical modification of surface groups of penicillin $G$ acylase followed by immobilization of the modified enzyme [115].

The selection of the best stabilization approach from the plethora of methods available is highly dependent on the enzyme-stabilizer interactions and possible changes in the catalytic efficiency of the enzymes. Optimized stabilization parameters will lead to more efficient enzymes as well as to an increase of the economic potential of the existing enzymatic processes in novel areas where the catalysts have not been applied due to their instability.

The growing replacement of conventional chemical methods in laboratories and industries by enzyme- 
based strategies demands continuous research and improvement of the stabilization strategies. New methods and/or combination of different techniques would allow to overcome the current limitations related with the enzyme stabilization decreasing costs and storage problems and improving commercialization.

\section{Disclosure statement}

No potential conflict of interest was reported by the authors.

\section{Funding}

The authors would like to thank Portuguese Science and Technology Foundation (FCT) under the scope of the strategic funding of UID/BIO/04469/2013 unit and COMPETE 2020 (POCl-01-0145-FEDER-006684) and BioTecNorte operation (NORTE-01-0145-FEDER-000004) funded by European Regional Development Fund under the scope of Norte2020 Programa Operacional Regional do Norte. They would like also to thank the Program for Changjiang Scholars and Innovative Research Team in University (IRT1135). This study was also supported by Chinese Government Scholarship under China Scholarship Council (No. 201606790036) and Chinese Foundation Key projects of governmental cooperation in International Scientific and Technological Innovation (No. 2016 YFE0115700).

\section{References}

[1] Kumar VSD, Sangwan P. Industrial enzymes trends: scope and relevance. 1st ed. Chapter: 10. In: Beniwal V, Sharma AK, editors. Global market scenario of industrial enzymes. India: Nova Science Publishers; 2014. p.173-196.

[2] Beilen JB, Li Z. Enzyme technology: an overview. Curr Opin Biotechnol. 2002;13:338-344.

[3] lyer PV, Ananthanarayan L. Enzyme stability and stabilization-aqueous and non- aqueous environment. Process Biochem. 2008;43:1019-1032.

[4] Ó'Fágáin C. Enzyme stabilization-recent experimental progress. Enzyme Microb Technol. 2003;33: 137-49.

[5] Kirk O, Borchert TV, Fuglsang CC. Industrial enzyme applications. Curr Opin Biotechnol. 2002;13:345-351.

[6] Gianfreda L, Scarfi MR. Enzyme stabilization: state of the art. Mol Cell Biochem. 1991;100:97-128.

[7] Horwitz J, Bova MP, Ding L, et al. crystallin: function and structure. Eye. 1999;13:403-408.

[8] Katyal N, Deep S. Revisiting the conundrum of trehalose stabilization. Phys Chem Chem Phys. 2014;16: 26746-26761.

[9] Chang BS, Yeung B. Physical stability of protein pharmaceuticals. formulation and process development strategies for manufacturing biopharmaceuticals. California: John Wiley \& Sons, Inc. 2010. p. 69-104.

[10] Robic S. Mathematics, thermodynamics, and modeling to address ten common misconceptions about protein structure, folding, and stability. CBE Life Sci Educ. 2010;9:189-195.

[11] Burioni R, Cassi D, Cecconi F, et al. Topological thermal instability and length of proteins. Proteins. 2004;55:529-535.

[12] Bommarius AS, Paye MF. Stabilizing biocatalysts. Chem Soc Rev. 2013;42:6534-6565.

[13] Saptarshi SR, Duschl A, Lopata AL. Interaction of nanoparticles with proteins: relation to bio-reactivity of the nanoparticle. J Nanobiotechnology. 2013;11: 26-21.

[14] Salloum DS, Schlenoff JB. Protein adsorption modalities on polyelectrolyte multilayers. Biomacromolecules. 2004;5:1089-1096.

[15] Jeong S. Analytical methods and formulation factors to enhance protein stability in solution. Arch Pharm Res. 2012;35:1871-1886.

[16] Sinha N, Mohan S, Lipschultz CA, et al. Differences in electrostatic properties at antibody-antigen binding sites: implications for specificity and cross-reactivity. Biophys J. 2002;83:2946-2968.

[17] Andrade JD, Hlady V. Protein adsorption materials biocompatibility: a tutorial review. Berlin Heidelberg: Springer, 1986. p. 1-63.

[18] van der Veen M, Norde W, Stuart MC. Electrostatic interactions in protein adsorption probed by comparing lysozyme and succinylated lysozyme. Colloids Surf B. 2004;35:33-40.

[19] Yano YF, Uruga T, Tanida H, et al. Protein salting out observed at an air-water interface. J Phys Chem Lett. 2011;2:995-999.

[20] Dill KA. Dominant forces in protein folding. Biochemistry. 1990;29:7133-7155.

[21] Shen DZ, Xue $\mathrm{YH}$, Kang $\mathrm{Q}$, et al. Monitoring of adsorption of lysozyme onto quartz using an electrode-separated piezoelectric sensor. Microchem J. 1998;60:1-7.

[22] Dobson CM. Protein folding and misfolding. Nature. 2003;426:884-890.

[23] Demirjian DC, Morís-Varas F, Cassidy CS. Enzymes from extremophiles. Curr Opin Chem Biol. 2001;5: 144-151.

[24] Bergquist PL, Morgan HW, Saul D. Selected enzymes from extreme thermophiles with applications in biotechnology. Curr Biotechnol. 2014;3:45-59.

[25] Haki GD, Rakshit SK. Developments in industrially important thermostable enzymes: a review. Bioresour Technol. 2003;89:17-34.

[26] Andrade CMMC Pereira Jr, N, Antranikian G. Extremely thermophilic microorganisms and their polymer-hidrolytic enzymes. Rev Microbiol. 1999;30: 287-298.

[27] Bornscheuer UT, Huisman GW, Kazlauskas RJ, et al. Engineering the third wave of biocatalysis. Nature. 2012;485:185-194.

[28] Davids T, Schmidt M, Böttcher D, et al. Strategies for the discovery and engineering of enzymes for biocatalysis. Curr Opin Chem Biol. 2013;17:215-220.

[29] Behrens GA, Hummel A, Padhi SK, et al. Discovery and protein engineering of biocatalysts for organic synthesis. Adv Synth Catal. 2011;353:2191-2215. 
[30] Lutz S. Beyond directed evolution-semi-rational protein engineering and design. Curr Opin Biotechnol. 2010;21:734-743.

[31] Bommarius AS, Blum JK, Abrahamson MJ. Status of protein engineering for biocatalysts: how to design an industrially useful biocatalyst. Curr Opin Chem Biol. 2011;15:194-200.

[32] Böttcher D, Bornscheuer UT. Protein engineering of microbial enzymes. Curr Opin Microbiol. 2010;13: 274-282.

[33] Woodley JM. Protein engineering of enzymes for process applications. Curr Opin Chem Biol. 2013;17: 310-316.

[34] Otten LG, Hollmann F, Arends IWCE. Enzyme engineering for enantioselectivity: from trial-and-error to rational design? Trends Biotechnol. 2010;28:46-54.

[35] Brode PF, Erwin CR, Rauch DS, et al. Subtilisin BPN'Variants: increased hydrolytic activity on surfacebound substrates via decreased surface activity. Biochemistry. 1996;35:3162-3169.

[36] Beer HD, Wohlfahrt G, McCarthy JEG, et al. Analysis of the catalyic mechanism of a fungal lipase using computer-aided design and structural mutants. Protein Eng Des Sel. 1996;9:507-517.

[37] Martinelle M, Holmquist M, Clausen IG, et al. The role of Glu87 and Trp89 in the lid of Humicola lanuginosa lipase. Protein Eng Des Sel. 1996;9:519-524.

[38] Pedersen S, Lange NK, Nissen AM. Novel industrial enzyme applications. Ann Ny Acad Sci. 1995;750: 376-390.

[39] Jegannathan KR, Nielsen PH. Environmental assessment of enzyme use in industrial production - a literature review. J Clean Prod. 2013;42:228-240.

[40] Koivula A, Reinikainen T, Ruohonen $L$, et al. The active site of Trichoderma reesei cellobiohydrolase II: the role of tyrosine 169. Protein Eng. 1996;9:691-699.

[41] Davis BG. Chemical modification of biocatalysts. Curr Opin Biotechnol. 2003;14:379-386.

[42] Vinogradov AA, Kudryashova EV, Grinberg VY, et al. The chemical modification of $\alpha$-chymotrypsin with both hydrophobic and hydrophilic compounds stabilizes the enzyme against denaturation in water-organic media. Protein Eng. 2001;14:683-689.

[43] Ueji S-i, Tanaka H, Hanaoka T, et al. Effects of chemical modification of lipase on its enantioselectivity in organic solvents. Chem Lett. 2001;30:1066-1067.

[44] Díaz-Rodríguez A, Davis BG. Chemical modification in the creation of novel biocatalysts. Curr Opin Chem Biol. 2011;15:211-219.

[45] Bund RK, Singhal RS. Chemical modification of cellulase by maleic anhydride and $\mathrm{N}$-bromosuccinimide for improved detergent stability. J Surfact Deterg. 2002;5:1-4.

[46] DeSantis G, Jones JB. Chemical modification of enzymes for enhanced functionality. Curr Opin Biotechnol. 1999;10:324-330.

[47] Quiocho FA, Richards FM. Intermolecular cross linking of a protein in the crystalline state: carboxypeptidase-A. Proc Natl Acad Sci USA. 1964;52:833-839.

[48] Govardhan CP. Crosslinking of enzymes for improved stability and performance. Curr Opin Biotechnol. 1999;10:331-335.
[49] Silva CJ, Sousa F, Guebitz G, Cavaco-Paulo A. Chemical modifications on proteins using glutaraldehyde. Food Technol Biotechnol. 2004;42:51-16.

[50] Mayolo-Deloisa K, González-González M, SimentalMartínez J, et al. Aldehyde PEGylation of laccase from Trametes versicolor in route to increase its stability: effect on enzymatic activity. J Mol Recognit. 2015;28:173-179.

[51] López-Cruz Jl, Viniegra-González G, HernándezArana A. Thermostability of native and pegylated myceliophthora thermophila laccase in aqueous and mixed solvents. Bioconjugate Chem. 2006;17: 1093-1098.

[52] Homaei AA, Sariri R, Vianello F, et al. Enzyme immobilization: an update. J Chem Biol. 2013;6:185-205.

[53] Asgher M, Shahid M, Kamal S, et al. Recent trends and valorization of immobilization strategies and ligninolytic enzymes by industrial biotechnology. J Mol Catal B Enzym. 2014;101:56-66.

[54] Ritter DW, Newton JM, McShane MJ. Modification of PEGylated enzyme with glutaraldehyde can enhance stability while avoiding intermolecular crosslinking. RSC Adv. 2014;4:28036-28040.

[55] Ansari SA, Husain Q. Potential applications of enzymes immobilized on/in nano materials: a review. Biotechnol Adv. 2012;30:512-523.

[56] Cowan DA, Fernandez-Lafuente R. Enhancing the functional properties of thermophilic enzymes by chemical modification and immobilization. Enzyme Microb Technol. 2011;49:326-346.

[57] Taylor RF. A comparison of various commerciallyavailable liquid chromatographic supports for immobilization of enzymes and immunoglobulins. Anal Chim Acta. 1985;172:241-248.

[58] Palomo JM. Lipases enantioselectivity alteration by immobilization techniques. Curr Bioact Comp. 2008;4: 126-138.

[59] Kamori M, Hori T, Yamashita Y, et al. Immobilization of lipase on a new inorganic ceramics support, toyonite, and the reactivity and enantioselectivity of the immobilized lipase. J Mol Catal B Enzym. 2000;9:269-274.

[60] Sangeetha K, Emilia Abraham T. Preparation and characterization of cross-linked enzyme aggregates (CLEA) of Subtilisin for controlled release applications. Int J Biol Macromol. 2008;43:314-319.

[61] Talekar S, Ghodake V, Ghotage T, et al. Novel magnetic cross-linked enzyme aggregates (magnetic CLEAs) of alpha amylase. Bioresour Technol. 2012; 123:542-547.

[62] Stepankova V, Bidmanova S, Koudelakova T, et al. Strategies for stabilization of enzymes in organic solvents. ACS Catal. 2013;3:2823-2836.

[63] Balcão VM, Vila MMDC. Structural and functional stabilization of protein entities: state-of-the-art. Adv Drug Deliv Rev. 2015;93:25-41.

[64] Hudson EP, Eppler RK, Clark DS. Biocatalysis in semiaqueous and nearly anhydrous conditions. Curr Opin Biotechnol. 2005;16:637-643.

[65] Scharnagl C, Reif M, Friedrich J. Stability of proteins: temperature, pressure and the role of the solvent. Biochim Biophys Acta. 2005;1749:187-213. 
[66] Miyawaki O. Hydration state change of proteins upon unfolding in sugar solutions. Biochim Biophys Acta. 2007;1774:928-935.

[67] Kumar V, Chari R, Sharma VK, et al. Modulation of the thermodynamic stability of proteins by polyols: significance of polyol hydrophobicity and impact on the chemical potential of water. Int J Plast. 2011;413:19-28.

[68] Saenger W. Structure and dynamics of water surrounding biomolecules. Annu Rev Biophys Biophys Chem. 1987;16:93-114.

[69] Arakawa T, Prestrelski SJ, Kenney WC, et al. Factors affecting short-term and long-term stabilities of proteins. Adv Drug Deliv Rev. 1993;10:1-28.

[70] Wong YH, Tayyab S. Protein stabilizing potential of simulated honey sugar cocktail under various denaturation conditions. Process Biochem. 2012;47: 1933-1943.

[71] Carpenter JF, Crowe JH. The mechanism of cryoprotection of proteins by solutes. Cryobiology. 1988;25: 244-255.

[72] Haque I, Singh R, Moosavi-Movahedi AA, et al. Effect of polyol osmolytes on $\Delta \mathrm{gD}$, the Gibbs energy of stabilisation of proteins at different $\mathrm{pH}$ values. Biophys Chem. 2005;117:1-12.

[73] Haque I, Singh R, Ahmad F, et al. Testing polyols' compatibility with Gibbs energy of stabilization of proteins under conditions in which they behave as compatible osmolytes. FEBS Lett. 2005;579:3891-3898.

[74] Ebel C, Eisenberg H, Ghirlando R. Probing proteinsugar interactions. Biophys J. 2000;78:385-393.

[75] Timasheff SN, Arakawa T. Mechanism of protein precipitation and stabilization by co-solvents. J Cryst Growth. 1988;90:39-46.

[76] Sanchez-Ruiz JM. Protein kinetic stability. Biophys Chem. 2010;148:1-15.

[77] Becktel WJ, Schellman JA. Protein stability curves. Biopolymers. 1987;26:1859-1877. Peptide Science Section.

[78] Miyawaki O, Tatsuno M. Thermodynamic analysis of alcohol effect on thermal stability of proteins. J Biosci Bioeng. 2011;111:198-203.

[79] Linhananta A, Hadizadeh S, Plotkin SS. An effective solvent theory connecting the underlying mechanisms of osmolytes and denaturants for protein stability. Biophys J. 2011;100:459-468.

[80] Kristjánsson MM, Kinsella JE. Protein and enzyme stability: structural, thermodynamic, and experimental aspects. In: John EK, editor. Advances in food and nutrition research. Netherlands: Academic Press; 1991. p. 237-316.

[81] Lavelle L, Fresco JR. Stabilization of nucleic acid triplexes by high concentrations of sodium and ammonium salts follows the Hofmeister series1. Biophys Chem. 2003;105:681-699.

[82] Kamiyama T, Sadahide $Y$, Nogusa $Y$, et al. Polyolinduced molten globule of cytochrome c: an evidence for stabilization by hydrophobic interaction. Biochim Biophys Acta. 1999;1434:44-57.

[83] Timasheff SN, Arakawa T. Mechanism of protein precipitation and stabilization by co-solvents. J Cryst Growth. 1988;90:39-46.
[84] Kherb J, Flores SC, Cremer PS. Role of carboxylate side chains in the cation hofmeister series. J Phys Chem B. 2012;116:7389-7397.

[85] Zhang Y, Cremer PS. The inverse and direct Hofmeister series for lysozyme. Proc Natl Acad Sci USA. 2009;106:15249-15253.

[86] Sedlák E, Stagg L, Wittung-Stafshede P. Effect of Hofmeister ions on protein thermal stability: Roles of ion hydration and peptide groups? Arch Biochem Biophys. 2008;479:69-73.

[87] Gao W-W, Zhang F-X, Zhang G-X, et al. Key factors affecting the activity and stability of enzymes in ionic liquids and novel applications in biocatalysis. Biochem Eng J. 2015;99:67-84.

[88] Zhao H. lonic liquids as (Co-)solvents for hydrolytic enzymes. Ionic liquids in biotransformations and organocatalysis. Hoboken (NJ): John Wiley \& Sons, Inc., 2012. p. 151-227.

[89] Weingartner $\mathrm{H}$, Cabrele $\mathrm{C}$, Herrmann C. How ionic liquids can help to stabilize native proteins. Phys Chem Chem Phys. 2012;14:415-426.

[90] Yang Z. Hofmeister effects: an explanation for the impact of ionic liquids on biocatalysis. J Biotechnol. 2009;144:12-22.

[91] Zhao H. Protein stabilization and enzyme activation in ionic liquids: specific ion effects. J Chem Technol Biotechnol. 2016;91:25-50.

[92] Shulgin IL, Ruckenstein E. Preferential hydration and solubility of proteins in aqueous solutions of polyethylene glycol. Biophys Chem. 2006;120:188-198.

[93] Liang Y, Yuan X, Zeng G, et al. Effects of surfactants on enzyme-containing reversed micellar system. Sci China Chem. 2011;54:715-723.

[94] Brown ED, Yada RY, Marangoni AG. The dependence of the lipolytic activity of Rhizopus arrhizus lipase on surfactant concentration in Aerosol-OT/isooctane reverse micelles and its relationship to enzyme structure. Biochim Biophys Acta. 1993;1161:66-72.

[95] Simpson RJ. Stabilization of Proteins for Storage. Cold Spring Harb Protoc. 2010;2010:pdb.top79.

[96] Hwang ET, Gu MB. Enzyme stabilization by nano/ microsized hybrid materials. Eng Life Sci. 2013;13: 49-61.

[97] Jia H, Zhu G, Wang P. Catalytic behaviors of enzymes attached to nanoparticles: the effect of particle mobility. Biotechnol Bioeng. 2003;84:406-414.

[98] Betancor L, Luckarift HR. Bioinspired enzyme encapsulation for biocatalysis. Trends Biotechnol. 2008;26: 566-572.

[99] Poulsen N, Sumper M, Kröger N. Biosilica formation in diatoms: characterization of native silaffin-2 and its role in silica morphogenesis. Proc Natl Acad Sci USA. 2003;100:12075-12080.

[100] Kim J, Grate JW, Wang P. Nanobiocatalysis and its potential applications. Trends Biotechnol. 2008;26: 639-646.

[101] Kim J, Grate JW. Single-enzyme nanoparticles armored by a nanometer-scale organic/inorganic network. Nano Lett. 2003;3:1219-1222.

[102] Kim J, Jia H, Lee C-w, et al. Single enzyme nanoparticles in nanoporous silica: a hierarchical approach to 
enzyme stabilization and immobilization. Enzyme Microb Technol. 2006;39:474-480.

[103] Yang Z, Si S, Zhang C. Magnetic single-enzyme nanoparticles with high activity and stability. Biochem Biophys Res Commun. 2008;29:169-175.

[104] Colletier J-P, Chaize B, Winterhalter $M$, et al. Protein encapsulation in liposomes: efficiency depends on interactions between protein and phospholipid bilayer. BMC Biotechnol. 2002;2:9.

[105] Zhou X-M, Entwistle A, Zhang H, et al. Self-assembly of amyloid fibrils that display active enzymes. ChemCatChem. 2014;6:1961-1968.

[106] Zhou X-M, Shimanovich U, Herling TW, et al. Enzymatically active microgels from self-assembling protein nanofibrils for microflow chemistry. ACS Nano. 2015;9:5772-5781.

[107] Song Y, Shimanovich U, Michaels TCT, et al. Fabrication of fibrillosomes from droplets stabilized by protein nanofibrils at all-aqueous interfaces. Nat Commun. 2016;7:12934.

[108] Li AB, Kluge JA, Guziewicz NA, et al. Silk-based stabilization of biomacromolecules. J Control Release. 2015;219:416-430.

[109] Montes T, Grazú V, López-Gallego F, et al. Genetic modification of the penicillin $G$ acylase surface to improve its reversible immobilization on ionic exchangers. Appl Environ Microbiol. 2007;73: 312-319.

[110] Fernandez-Lafuente $R$, Rosell CM, Caanan-Haden L, et al. Facile synthesis of artificial enzyme nano-environments via solid-phase chemistry of immobilized derivatives: dramatic stabilization of penicillin acylase versus organic solvents. Enzyme Microb Technol. 1999;24:96-103.

[111] Abian O, Mateo C, Fernández-Lorente $G$, et al. Stabilization of immobilized enzymes against watersoluble organic cosolvents and generation of hyperhydrophilic micro-environments surrounding enzyme molecules. Biocatal Biotransformation. 2001;19: 489-503.

[112] Hassani L, Ranjbar B, Khajeh K, et al. Horseradish peroxidase thermostabilization: the combinatorial effects of the surface modification and the polyols. Enzyme Microb Technol. 2006;38:118-125.

[113] Chan L, Cross HF, She JK, et al. Covalent attachment of proteins to solid supports and surfaces via sortase-mediated ligation. PLoS One. 2007;2:e1164.

[114] László K, Szava A, Mária Simon L. Stabilization of various $\alpha$-chymotrypsin forms in aqueous-organic media by additives. J Mol Catal B Enzym. 2001;16:141-146.

[115] Montes T, Grazu V, López-Gallego F, et al. Chemical modification of protein surfaces to improve their reversible enzyme immobilization on ionic exchangers. Biomacromolecules. 2006;7:3052-3058.

[116] Araújo R, Casal M, Cavaco-Paulo A. Application of enzymes for textile fibres processing. Biocatal Biotransformation. 2008;26:332-349.

[117] Chand N, Nateri AS, Sajedi RH, et al. Enzymatic desizing of cotton fabric using a $\mathrm{Ca}^{2+}$-independent $\alpha$-amylase with acidic $\mathrm{pH}$ profile. J Mol Catal B Enzym. 2012;83:46-50.
[118] Levene R, Cohen Y, Barkai D. Applying proteases to confer improved shrink resistance to wool. J Soc Dyers Colour. 1996;112:6-10.

[119] Freddi G, Mossotti R, Innocenti R. Degumming of silk fabric with several proteases. J Biotechnol. 2003;106: 101-112.

[120] Shen J, Rushforth M, Cavaco-Paulo A, et al. Development and industrialisation of enzymatic shrink-resist process based on modified proteases for wool machine washability. Enzyme Microb Technol. 2007;40:1656-1661.

[121] Araújo R, Silva C, Machado R, et al. Proteolytic enzyme engineering: a tool for wool. Biomacromolecules. 2009;10:1655-1661.

[122] Hajighasemi $M$, Nocek BP, Tchigvintsev $A$, et al. Biochemical and structural insights into enzymatic depolymerization of polylactic acid and other polyesters by microbial carboxylesterases. Biomacromolecules. 2016;17:2027-2039.

[123] Yang $Y, Y u$ Y, Zhang $Y$, et al. Lipase/esterasecatalyzed ring-opening polymerization: a green polyester synthesis technique. Process Biochem. 2011;46: 1900-1908.

[124] Silva CM, Carneiro F, O'Neill A, et al. Cutinase-a new tool for biomodification of synthetic fibers. J Polym Sci A Polym Chem. 2005;43:2448-2450.

[125] Ronkvist ÅM, Xie W, Lu W, et al. Cutinase-catalyzed hydrolysis of poly(ethylene terephthalate). Macromolecules. 2009;42:5128-5138.

[126] Matamá T, Araújo R, Gübitz GM, et al. Functionalization of cellulose acetate fibers with engineered cutinases. Biotechnol Progress. 2010;26: 636-643.

[127] Araújo R, Silva C, O'Neill A, et al. Tailoring cutinase activity towards polyethylene terephthalate and polyamide 6,6 fibers. J Biotechnol. 2007;128:849-857.

[128] Galli C, Gentili P, Jolivalt C, et al. How is the reactivity of laccase affected by single-point mutations? Engineering laccase for improved activity towards sterically demanding substrates. Appl Microbiol Biotechnol. 2011;91:123-131.

[129] Zhang Z-G, Yi Z-L, Pei X-Q, et al. Improving the thermostability of Geobacillus stearothermophilus xylanase XT6 by directed evolution and site-directed mutagenesis. Bioresour Technol. 2010;101:9272-9278.

[130] Singh RK, Zhang Y-W, Nguyen N-P-T, et al. Covalent immobilization of $\beta-1,4$-glucosidase from Agaricus arvensis onto functionalized silicon oxide nanoparticles. Appl Microbiol Biotechnol. 2011;89:337-344.

[131] Cristóvão RO, Silvério SC, Tavares APM, et al. Green coconut fiber: a novel carrier for the immobilization of commercial laccase by covalent attachment for textile dyes decolourization. World J Microbiol Biotechnol. 2012;28:2827-2838.

[132] Silva CJSM Zhang Q, Shen J, et al. Immobilization of proteases with a water soluble-insoluble reversible polymer for treatment of wool. Enzyme Microb Technol. 2006;39:634-640.

[133] Silva C, Silva CJ, Zille A, et al. Laccase immobilization on enzymatically functionalized polyamide 6,6 fibres. Enzyme Microb Technol. 2007;41:867-875. 
[134] Miletić N, Nastasović A, Loos K. Immobilization of biocatalysts for enzymatic polymerizations: possibilities, advantages, applications. Bioresour Technol. 2012;115:126-135.

[135] Stavila E, Arsyi RZ, Petrovic DM, et al. Fusarium solani pisi cutinase-catalyzed synthesis of polyamides. Eur Polymer J. 2013;49:834-842.

[136] Zhao H, Olubajo O, Song Z, et al. Effect of kosmotropicity of ionic liquids on the enzyme stability in aqueous solutions. Bioorg Chem. 2006;34:15-25.

[137] Yoshimoto M. Stabilization of enzymes through encapsulation in liposomes. In: Minteer DS, editor. Enzyme stabilization and immobilization: methods and protocols. Totowa, NJ: Humana Press; 2011. p. 9-18.

[138] Yang K, Xu N-S, Su WW. Co-immobilized enzymes in magnetic chitosan beads for improved hydrolysis of macromolecular substrates under a time-varying magnetic field. J Biotechnol. 2010;148:119-127.

[139] Martins M, Azoia N, Silva C, et al. Stabilization of enzymes in micro-emulsions for ultrasound processes. Biochem Eng J. 2015;93:115-118.

[140] Lu S, Wang X, Lu Q, et al. Stabilization of enzymes in silk films. Biomacromolecules. 2009;10:1032-1042.

[141] Demura M, Asakura T, Kuroo T. Immobilization of biocatalysts with bombyx mori silk fibroin by several kinds of physical treatment and its application to glucose sensors. Biosensors. 1989;4: 361-372.

[142] Shaw KL, Grimsley GR, Yakovlev Gl, et al. The effect of net charge on the solubility, activity, and stability of ribonuclease Sa. Protein Sci Soc. 2001;10: 1206-1215. 